\title{
Model Struktural Hubungan Antara Kepercayaan Epistemologis Dengan Konsepsi Tentang Belajar Dan Mengajar Mahasiswa
}

\author{
M. Nur Ghufron \\ Sekolab Tinggi Agama Islam Negeri Kudus \\ emnurghufron78@gmail.com \\ Indiyati Eko P, Berliana Henu Cahyani \\ Universitas Sarjana Wiyata Tamansiswa Yogyakarta \\ ind_psiust@yaboo.co.id
}

\begin{abstract}
This research aimed to assessing whether epistemological beliefs as measured by belief about knowledge and belief about learning predicted of the constructivist conception of teaching and learning, assessing whether epistemological beliefs as measured by belief about knowledge and belief about learning predicted of the traditional conception of teaching and learning. Thepopulation in this research consists of students of Tarbiyah Department of STAIN Kudus, Central Java. The sample was as many as study 242 students, taken through simple random sampling method. The data collection techniques used in this research was questionnaire in the form of scales and checklists. The data were analyzed using Structural Equation Models (SEM). The research resulted that epistemological beliefs as measured by belief about learning was negatively related on the constructivist conception of teaching and learning and) epistemological beliefs as measured by belief about knowledge was positively related on the traditional conception of teaching and learning.
\end{abstract}

Keywords: epistemological beliefs and conceptions' of teaching and learning

\begin{abstract}
Abstrak
Penelitian ini bertujuan untuk mengetahui apakah kepercayaan epistemologis yang diukur dengan kepercayaan pada pengetabuan berpengarub terhadap konsepsi tentang belajar dan mengajar konstruktivisme dan tradisional mahasiswa dan, mengetabui apakah kepercayaan epistemologis yang diukur dengan kepercayaan pada belajar berpengarub terhadap konsepsi tentang belajar dan mengajar konstruktivisme dan tradisional mahasiswa. Populasi dalam penelitian ini adalah mahasiswamahasiswi Jurusan Tarbiyah, STAIN Kudus. Sampel penelitian ini berjumlah 242 yang diambil melalui tehnik pengambilan sampel simple random sampling. Adapun teknik pengumpulan data yang digunakan dalam penelitian ini adalah kuesioner dalam bentuk skala, dan daftar isian. Data dianalisis dengan menggunakan Model Persamaan Struktural atau Structural Equation Modeling (SEM). Hasil penelitian variabel kepercayaan pada belajar berpengarub (negatif) terhadap konsepsi tentang belajar dan mengajar konstruktivisme dan variabel kepercayaan pada pengetahuan berpengaruh (positif) terhadap konsepsi tentang belajar dan mengajar tradisional.
\end{abstract}

Kata Kunci: Kepercayaaan epistemologis, konsepsi tentang belajar dan mengajar Permalink/DOI:http://dx.doi.org/10.18326/infsl3.v11i1.51-74 


\section{Pendahuluan}

Indonesia, apabila dilihat dari jumlah penduduk, termasuk negara yang memiliki sumber daya manusia yang besar. Sampai saat ini pengembangan sumber daya manusia masih merupakan topik utama dalam pembangunan bangsa. Para pakar pada umumnya merasakan dan menyadari bahwa Indonesia meskipun secara potensial memiliki sumber daya alam dan manusia yang kaya, namun dalam hal pemanfaatannya dan peningkatannya masih jauh tertinggal.

Kemudian dalam rangka meningkatkan kualitas sumber daya manusia, pendidikan harus digarap dengan serius. Pengembangan pendidikan perlu senantiasa dilakukan untuk menciptakan sumber daya manusia handal yang mampu bersaing di era globalisasi ini. Penguasaan terhadap ilmu pengetahuan juga merupakan prasyarat bagi manusia untuk menjadi wakil Tuhan (khalîfah) di bumi dalam rangka memakmurkan dunia.

Pada saat ini, belajar dan bekerja secara profesional menjadi tuntutan pada pembangunan berkelanjutan (Tynjälä, 1999: 357). Selain itu, belajar seumur hidup telah menjadi kompetensi penting untuk kemajuan pribadi dan profesional dalam masyarakat berpengetahuan. Tantangan untuk pendidikan tinggi adalah untuk memfasilitasi proses pembelajaran yang memungkinkan mahasiswa membangun dan merekonstruksi pengetahuan, dan untuk menguasai sebuah struktur terpadu pengetahuan dan keterampilan yang relevan dengan tempat kerja yang professional (Otting, Zwaal, Tempelaar dan Gijselaers, 2010: 741).

Namun demikian, kontribusi pendidikan tinggi terhadap masyarakat berpengetahuan secara intensif haruslah tidak hanya sekedar menyampaikan pengetahuan dan keterampilan, akan tetapi hendaknya juga bertujuan pada penciptaan terus-menerus pengetahuan baru dan penerapan pengetahuan secara profesional dalam kehidupan. Bagaimana mahasiswa membangun pengetahuan serta bagaimana mahasiswa belajar, telah menjadi isu utama dalam pendidikan tinggi (Otting, Zwaal, Tempelaar dan Gijselaers, 2010: 741-742). 
Penelitian kepercayaan mahasiswa tentang sifat pengetahuan dan bagaimana mengetahui atau sering disebut kepercayaan epistemologis, berhubungan dengan ide-ide mahasiswa tentang pengetahuan dan belajar, serta dapat menyebabkan pemahaman yang lebih baik tentang bagaimana pengembangan intelektual serta pembelajaran yang dilakukan mahasiswa (Hofer 2001: 369-370).

Berbagai penelitian menunjukan bahwa kepercayaan epistemologis individu berpengaruh terhadap perbedaan aspek dalam proses belajar (Ryan, 1984: 1226-1238), berpengaruh terhadap prestasi belajar (Schommer, 1993a: 355-370; 1993b: 406-411; Bra ten \& Strømsø, 2006: 1027-1042), mempertinggi pengelolaan diri dalam belajar, sehingga menurunkan tingkat penundaan akademik (Boffeli, 2007: ii), intensitas belajar dengan giat (Liem dan Bernardo, 2010: 127-142).

Selain itu, kepercayaan epistemologis berpengaruh terhadap penggunaan pendekatan dalam belajar (Cano, 2005: 203-221; Chan, 2003: 36-50; 2004: 1-13; 2007: 36-50; Phan, 2006: 577-610, 2008: 157184; Tsai, 2000: 193-205; Tsai \& Chuang, 2005: 97-100; Bra ${ }^{\circ}$ ten\& Strømsø, 2006b: 1027-1042; Barnard, Lan, Crooks, Paton, 2008: 261-266). Hasil Metaanalisis terhadap 52 penelitian kepercayaan epistemologis yang dihubungkan dengan pendekatan belajar yang dilakukan oleh Ghufron (2009: 130) menyimpulkan bahwa kepercayaan epistemologis secara perdimensi (certain knowledge, simple knowledge, authority/expert knowledge, fixed/innate ability, dan effort/process/quick learning) dan kepercayaan epistemologis yang tidak teridentifikasi dimensinya, dapat dijadikan prediktor individu dalam memilih pendekatan belajar yang akan digunakan. Kelima dimensi kepercayaan epistemologis tersebut membentuk pola hubungan dan alasan yang berbeda saat digunakan sebagai pendekatan dalam belajar.

Beberapa hasil penelitian (seperti Chan, 2004: 1-13; Chai, Teo, \& Lee, 2010: 25-42; Otting, Zwaal, Tempelaar dan Gijselaers, 2010: 741-760; dan Lee, 2011: vii-viii) menunjukkan bahwa kepercayaan epistemologis berpengaruh signifikan terhadap konsepsi tentang mengajar mahasiswa pendidikan guru. Posisi kepercayaan epistemologis juga dapat menentukan posisi konsepsi tentang 
mengajar yang dimiliki mahasiswa pendidikan guru bahkan dapat mengembangkan konsepsi tentang mengajarnya.

Hasil penelitian Chan dan Elliott (2004: 123-142) menunjukkan bahwa kepercayaan epistemologis pada dimensi belajar dan kemampuan otoritas / pakar, dan pengetahuan kepastian berkorelasi dengan konsepsi tentang belajar dan mengajar tradisional, dan belajar sebagai proses berkorelasi dengan konsepsi tentang belajar dan mengajar konstruktivis.

Para peneliti di bidang pendidikan seperti Hofer \& Pintrich (1997: 88-140), mengklaimbahwakepercayaanepistemologismemainkanperan penting di dalam perilaku-perilaku akademis, seperti mempengaruhi penggunaan teknik-teknik dalam belajar, sebagai contoh, para pelajar yang percaya bahwa struktur pengetahuan terdiri dari potonganpotongan yang tidak bertalian dengan informasi, kemungkinan akan menggunakan teknik menghafal sebagai teknik belajar dan bukan tehnik pemahaman. Penelitian ini juga menyimpulkan bahwa para pelajar yang memandang bahwa pengetahuan sama yang tak berubah dan stabil cenderung menggunakan tehnik menghafal fakta-fakta ilmiah. Berbeda dengan para pelajar yang memandang pengetahuan dinamis, yang akan lebih mengutamakan aspek pemahaman informasi (Davis, 1997: 3). Lebih dari itu, para pelajar yang percaya bahwa tehnik memahami adalah strategi terbaik dalam belajar, akan mempunyai hasil yang lebih baik pada saat ujian akhir dibandingkan dengan pada para pelajar yang percaya bahwa tehnik menghafal adalah tehnik yang terbaik (Davis, 1997: 3).

Penelitian Schommer (1993a: 355-370) dengan mengendalikan pengukuran inteligensi, menghasilkan bahwa prediktor yang paling kuat dalam menentukan prestasi belajar pada pelajar Sekolah Menengah Atas adalah kepercayaan bahwa belajar terjadi melalui proses yang berangsur-angsur. Semakin kuat kepercayaan belajar terjadi, semakin tinggi pula prestasi belajarnya. Pada tingkat perguruan tinggi, ditemukan bahwa mahasiswa yang percaya bahwa pengetahuan bersifat sederhana, mempunyai lebih banyak kesukaran dalam memahami pelajaran matematika (Schoenfeld, 1983: 329-363), konsepsi ilmiah (Songer \& Linn, 1991: 761-784), dan bahasa asing (Horwitz, 1988: 283-294). 
Bra ten dan Strømsø (2005: 539-565) menemukan pada mahasiswa yang percaya bahwa pengetahuan bersifat stabil dan hanya bisa diperoleh melalui otoritas pengajar, akan lebih sedikit mempunyai tujuan berorientasi pemahaman dan lebih banyak berorientasi penghafalan. Karenanya, memahami peran kepercayaan epistemologis adalah penting dalam membantu para pembelajar dalam menggunakan strategi belajar yang efektif guna mencapai tujuan akademis. Peterson (dalam Brownlee, Thorpe dan Stacey, 2005: 1) menyatakan sebagai berikut. "Karena pendidikan berhubungan dengan pengetahuan, maka kepercayaan epistemologis dalam pendidikan sangat fundamental posisinya."

Berdasarkan penjelasan diatas tujuan penelitian ini adalah untuk mengetahui apakah kepercayaan epistemologis yang diukur dengan kepercayaan pada pengetahuan dan kepercayaan pada belajar berpengaruh terhadap konsepsi tentang belajar dan mengajar konstruktivisme dan untuk mengetahui apakah kepercayaan epistemologis yang diukur dengan kepercayaan pada pengetahuan dan kepercayaan pada belajar berpengaruh terhadap konsepsi tentang belajar dan mengajar tradisional.

\section{Konsepsi tentang Belajar dan Mengajar}

Konsepsi tentang belajar dan mengajar adalah keyakinan yang dipegang oleh mahasiswa atau guru tentang cara yang disukai dalam melakukan proses belajar dan mengajar. Selain itu, termasuk tentang makna belajar dan mengajar serta peran guru terhadap murid ataupun sebaliknya peran murid terhadap guru (Chan \& Elliot, 2004: 817-831).

Kember (1997: 255-275) melakukan analisis terhadap 13 penelitian mengenai definisi dari konsepsi tentang belajar dan mengajar dengan tujuan untuk menemukan elemen kunci dari definisi konsepsi tentang belajar dan mengajar. Terdapat dua dua orientasi kunci konsepsi tentang belajar dan mengajar yaitu, terpusat pada guru/orentasi isi (teachercentered/content-oriented) dan terpusat pada peserta didik (studentcentered/learning-oriented). Kember juga menambahkan satu kategori lagi, yang disebut interaksi siswa-guru, untuk menghubungkan dua 
orientasi. Kelima konsepsi tentang bawah ini orientasi diidentifikasi dalam kontinum sebagai berikut: (1) menanamkan informasi, (2) transmisi pengetahuan secara terstruktur, (3) interaksi guru-murid, (4) pemahaman fasilitator, dan (5) perubahan konsepsi.

Chan and Elliott (2004: 817-831) membagi konsepsi tentang belajar dan mengajar menjadi dua macam yaitu pertama, konsepsi tentang belajar dan mengajar konstruktivisme adalah konsepsi individu tentang belajar dan mengajar yang meliputi aspek; (1) belajar adalah penciptaan makna dengan penalaran peserta didik, dan (2) pengajaran dipandang sebagai fasilitas dari proses pembelajaran. Secara umum dapat pula dikatakan bahwa semakin tinggi nilai yang diperoleh semakin naif kepercayaan pada belajar yang dimiliki. Kedua konsepsi tentang belajar dan mengajar tradisional adalah konsepsi individu tentang belajar dan mengajar yang meliputi aspek; (1) pengajaran dipandang sebagai transfer pengetahuan dari otoritas atau ahli untuk seorang pemula, dan (2) pembelajaran disamakan untuk menerima pengetahuan. Secara umum dapat pula dikatakan bahwa semakin tinggi nilai yang diperoleh semakin naif kepercayaan pada belajar yang dimiliki.

Hasil penelitian Chan (2007: 1-13) pada mahasiswa Pendidikan Guru di Hongkong menunjukkan bahwa secara umum konsepsi tentang belajar dan mengajar dibagi menjadi dua yaitu konsepsi tradisional dan konsepsi konstruktivisme. Penelitian dengan instrument yang sama dilakukan di Singapura oleh Chan, Tan, dan Khoo (2007: 181-195) pada mahasiswa pendidikan guru yang menghasilkan bahwa konsepsi tentang belajar dan mengajar konstruktivisme dapat dijelaskan melalui perubahan filsafat pendidikan dari yang terpusat pada pengajar kepada yang terpusat pada peserta didik. Selain itu, lingkungan pembelajaran berbasis pemecahan masalah merupakan cermin pengaruh konsepsi tentang belajar dan mengajar dengan pendekatan konstruktivisme.

\section{Kepercayaan Epistemologis}

Secara etimologis, epistemologi berasal dari bahasa Yunani dari gabungan kata "episteme" dan "logos". Episteme berarti pengetahuan 
(Zerin, 1995: 150), sedangkan logos lazimnya menunjukkan teori atau pengetahuan secara sistemik. Penelitian tentang epistemologi menengarai tentang apakah sumber pengetahuan itu?, apa batasanya? bagaimanakah cara mementukan kebenaran pengetahuan itu? dan bagaimanakah cara mendapatkan pengetahuan? (King \& Magolda, 1996: 164). Dengan pengertian ini epistemologitentu saja menentukan karakter pengetahuan, bahkan menentukan kebenaran; macam apa yang dianggap patut diterima dan apa yang patut ditolak.

Adapun perbedaan penelitian epistemologi dalam filsafat dan psikologi pendidikan menurut Schommer (1994; 294) adalah apabila di dalam filsafat epistemologi mefokuskan pada investigasi tentang "kebenaran", "universal" dan "absolut" pengetahuan sedangkan dalam psikologi pendidikan mefokuskan tentang bagaimana kepercayaan individu tentang sifat pengetahuan dan pengaruh mengetahui terhadap proses kognitif. Sedangkan Hofer (2001; 353) mendefinisikan epistemologi dalam psikologi pendidikan berupa bagaimana kepercayaan-kepercayaan individu tentang bagaimana pengetahuan terjadi, seberapa banyak pengetahuan yang didapat, di mana di dapatkan dan bagaimana pengetahuan dikonstruksi dan dievaluasi.

Berdasarkan penjelasan di atas dapat disimpulkan bahwa kepercayaan epistemologi adalah kepercayaan-kepercayaan individu tentang sifat pengetahuan dan bagaiamana pengetahuan tersebut di dapatkan.

Schommer (1994; 2004) membuat sebuah model epistemic multidimensi (Epistemic Multidimensional Model), atau sering pula disebut model sistem melekat (Embedded System Model), untuk menjelaskan elemen dasar system kepercayaan epistemologis. Penelitian sebelumnya menemukan bahwa kepercayaan epistemologis masih sangat komplek dan unidimensi dan mefokuskan pada keunikan aspek epistemologis individu. Sebagai alternative Schommer (2004; 19-29) mengajukan kepercayaan epistemologis yang bisa dikatakan mengkonsep ulang berbagai system atau kepercayaan independent. Sistem kepercayaan yang di maksud adalah kepercayaan epistemologis yang multi dimensi yang terdapat lebih dari satu kepercayan yang dijadikan pertimbangan. 
Limataksonomikepercayaanyang diajukanSchommermeliputi kepercayaan tentang; (1) Pengetahuan bersifat sederhana (simple knowledge) misalnya pengetahuan terorganisir secara sederhana atau terpotong-potong ataukah mempunyai keterkaitan berbagai konsep, (2) Pengetahuan bersifat pasti (certain knowledge), bersifat absolute, menetap atau berkembang, (3) Pengetahuan berasal dari orang yang lebih tahu (omniscient), dari pengalaman orang yang mempunyai authoritas dalam menyampaikan pengetahuan atau berasal dari pemikiran sendiri diikuti dengan berbagai bukti, (4) Belajar dengan cepat (quick learning) seperti mahir dengan cepat atau bertahap melalui proses dengan mudah atau perlu kerja keras, dan (5) Kecakapan/kecerdasan dalam memperoleh pengetahuan (innate ability) yang bersifat bawaan yang menetap atau dapat berubah atau dapat berkembang setiap saat.

Hipotesis asli dari kepercayaan yang diajukan Schommer tersebut meliputi kepercayaan tentang: (a) struktur pengetahuan (the structur of knowledge); (b) stabilitas pengetahuan (stability of knowledge); (c) sumber pengetahuan (the sources of knowledge); (d) kecepatan belajar (the speed of learning); dan (e) kemampuan atau kecakapan bawaan (innate ability) dalam memperoleh pengetahuan.

Pada tahun Schommer-Aikins (2004: 19-29) mengajukan sebuah model yang ia beri nama model sistemik yang melekat (embedded systemic model). Berdasarkan perkembangan pemikiran kepercayaan epistemologis ini, Schommer memisahkan kepercayaan tentang pengetahuan dan kepercayaan tentang belajar, meski hal ini berlawanan dengan apa yang dilakukannya di tahun 1990. Schommer-Aikins percaya, pemisahan ini adalah untuk meramal hubungan timbal balik antara kepercayaan tentang pengetahuan dan kepercayaan tentang belajar.

Pada penelitian ini, kepercayaan epistemologis secara umum dibagi menjadi kepercayaan tentang hakekat pengetahuan dan kepercayaan tentang hakekat belajar. Kepercayaan tentang hakekat pengetahuan terdiri dari tiga dimensi yaitu:

Pertama, bahwa pengetahuan berasal dari orang yang lebih tahu atau lebih ahli (authority/expert knowledge) seperti dosen atau 
buku-buku referensi, dibandingkan dengan logika dan pemikiran sendiri. Pada dimensi ini, mahasiswa tidak mempunyai perspektif pengetahuan, sehingga percaya bahwa informasi dari buku referensi adalah benar, dan bahwa pengajar mesti menyampaikan materi dalam proses pembelajaran (Schommer, 1990: 498-504). Hal ini berbeda pada mahasiswa yang mempunyai kepercayaan epistemologis yang lebih canggih, yang lebih menekankan pada pengertian bahwa pengetahuan berasal dari konstruksi pemikiran sendiri.

Kedua, bahwa pengetahuan bersifat pasti (certain knowledge), absolut, tidak berubah, dan tidak tentatif. Mahasiswa yang mempunyai kepercayaan epistemologis yang canggih, cenderung mempercayai bahwa pengetahuan bersifat tentatif dan tidak bisa diperkirakan, dan tidak mempercayai bahwa pengetahuan bersifat pasti dan tidak bisa berubah (Jehng, Johnson, \& Anderson, 1993).

Ketiga, proses yang teratur (orderly process). Jehng, Johnson, \& Anderson, (1993: 23-25) memaparkan bahwa dimensi proses yang teratur, atau yang disebut juga dengan belajar secara keras (rigid learning), adalah dimensi kepercayaan tentang apakah belajar merupakan suatu proses bahwa individu secara pasif menerima pengetahuan yang sudah jadi, ataukah proses memformulasi faktafakta yang individu secara mandiri membangun gagasan-gagasan mereka. Dalam dimensi ini, perspektif mahasiswa lebih menyukai belajar dengan mengambil materi secara persis atau sama dengan apa yang mereka baca di buku referensi dan cenderung mengikuti apa yang tertulis di sana dari awal sampai akhir (Jehng, dkk., 2325). Belajar merupakan suatu proses yang teratur dengan hanya menerima secara pasif apa yang disampaikan oleh pengajar. Mereka sering menunjukkan perilaku-perilaku belajar yang dilakukan secara kaku seperti menghafalkan fakta-fakta tanpa memahaminya secara menyeluruh, kurang memperhatikan berbagai hal dari perspektif yang berbeda, dan menerima otoritas-otoritas tanpa mengevaluasinya secara seksama.

Adapun kepercayaan tentang hakekat belajar terdiri dari dua dimensi yaitu: 
Pertama, belajar dengan cepat (quick learning). Pada dimensi ini, mahasiswa memiliki perspektif yang mempercayai bahwa untuk memahami sesuatu sangat tergantung pada saat pertama kali mempelajarinya. Mahasiswa yang mempunyai strategi belajar yang baik, percaya bahwa belajar melalui proses kerja keras dapat meningkatkan efektivitas strategi belajar yang mereka gunakan. Kedua, kemampuan atau kecakapan bawaan (Innate Ability). Kemampuan bawaan merupakan tingkat dari kepercayaan bahwa kemampuan untuk belajar bersifat pembawaan, daripada diperoleh atau didapatkan (Jehng dkk., 1993: 23-25). Pada dimensi ini, mahasiswa berperspektif bahwa mahasiswa yang baik tidak harus belajar dengan giat di kampus karena sebagian manusia dilahirkan dengan membawa cara belajar yang baik bagi dirinya, contohnya dapat ditemukan pada dua penelitian yang dilakukan oleh Schoenfeld (dalam Jehng dkk., 1993: 23-25) yang menemukan bahwa hanya siswa yang berbakatlah yang berjiwa kreatif dan sukses dalam memecahkan permasalahan matematis.

Berdasarkan penjelasan di atas dapat disimpulkan bahwa kepercayaan epistemologis dibagi; pertama kepercayaan terhadap sifat pengetahuan adalah kepercayaan individu tentang sifat pengetahuan yang meliputi aspek; (1) pengetahuan berasal dari orang yang lebih tahu/seorang yang ahli (authority/ expert Knowledge), (2) pengetahuan yang sifatnya pasti (certain knowledge), dan (3) proses yang teratur (orderly process). Kedua, kepercayaan terhadap belajar adalah kepercayaan individu pada belajar yang meliputi; (1) belajar dengan cepat (quick learning) dan (2) kemampuan atau kecakapan bawaan (innate ability).

\section{Metode Penelitian}

Variabel Penelitian

Variabel yang terlibat dalam penelitian ini mencakup variabel eksogen (bebas/independen) yaitu: (a) kepercayaan pada sifat pengetahuan dan (b) kepercayaan pada belajar, sedangkan variabel endogen (terikat/dependen) yaitu: (a) konsepsi tentang belajar dan mengajar konstruktivisme dan (b) konsepsi tentang belajar dan mengajar tradisional. 


\section{Populasi dan Sampel Penelitian}

Populasi dalam penelitian ini adalah mahasiswa-mahasiswi Jurusan Tarbiyah Sekolah Tinggi Agama Islam Negeri (STAIN) Kudus, Jawa Tengah. Adapun tehnik pengambilan sampel dalam penelitian ini adalah simple random sampling. Dalam penelitian ini besarnya sampel ditentukan berdasarkan tabel Morgan (dalam Stephen dan William; 1981) yang kemudian dilakukan random dengan bantuan program perangkat lunak Statistical Package for Social Science (SPSS). Setelah dilakukan perandoman didapatkan 242 orang mahasiswa Jurusan Tarbiyah Sekolah Tinggi Agama Islam Negeri (STAIN) Kudus.

\section{Instrumen Pengumpulan Data}

Sesuai dengan rancangan penelitian, penelitian ini melibatkan variabel, kepercayaan epistemologis, yang dibagi menjadi dua pengukuran yaitu kepercayaan pada sifat pengetahuan dan kepercayaan kepada belajar, dan variabel konsepsi tentang belajar dan mengajar konstruktivisme dan konsepsi tentang belajar dan mengajar tradisional. Adapun teknik pengumpulan data yang digunakan adalah kuesioner dalam bentuk skala.

\section{Tehnik Analisis Data}

Teknik untuk menganalisis data dalam penelitian ini menggunakan Model Persamaan Struktural atau Structural Equation Modeling (SEM).

\section{Hasil Penelitian Dan Pembahasan}

Responden penelitian ini berjumlah 242 orang mahasiswa Jurusan Tarbiyah Sekolah Tinggi Agama Islam Negeri (STAIN) Kudus. Gambaran umum karakteristik sampel penelitian yang berjenis kelamin laki-laki berjumlah 98 orang, dan sampel yang berjenis kelamin perempuan berjumlah 144 orang. Usia sampel penelitian ini berkisar antara 18 tahun sampai 26 tahun. Mahasiswa yang berasal dari program studi Pendidikan Agama Islam berjumlah 189, dan 
yang berasal program studi Pendidikan Bahasa Arab berjumlah 53 orang.

Pada penelitian ini terdapat empat variabel laten, yaitu (a) kepercayaan pada pengetahuan, (b) kepercayaan pada belajar, (c) konsepsi tentang belajar dan mengajar konstruktivisme dan (d) konsepsi tentang belajar dan mengajar tradisional. Secara lengkap data statistik deskriptif masing-masing variabel tersaji pada tabel berikut ini.

Tabel 2. Statistic deskriptif masimg-masing variabel

\begin{tabular}{|c|c|c|c|c|c|}
\hline & $\mathrm{N}$ & Minimum & Maximum & Mean & $\begin{array}{l}\text { Std. } \\
\text { Deviation }\end{array}$ \\
\hline $\begin{array}{l}\text { Kepercayaan pada } \\
\text { Pengetahuan }\end{array}$ & 242 & 6 & 28 & 20.45455 & 4.986 \\
\hline $\begin{array}{l}\text { Kepercayaan pada } \\
\text { Belajar }\end{array}$ & 242 & 5 & 22 & 14.88017 & 3.297 \\
\hline $\begin{array}{l}\text { Konsepsi tentang } \\
\text { Belajar dan Mengajar } \\
\text { Konstruktivisme } \\
\text { Konsepsi tentang }\end{array}$ & 242 & 0 & 16 & 8.805785 & 4.032 \\
\hline $\begin{array}{l}\text { Belajar dan Mengajar } \\
\text { Tradisional } \\
\text { Valid N (listwise) }\end{array}$ & $\begin{array}{l}242 \\
242\end{array}$ & 2 & 24 & 12.7438 & 6.183 \\
\hline
\end{tabular}

Hasil Uji Analisis Faktor Konfirmatoris dan Uji Hipotesis

Sebelum dilakukan analisis model persamaan struktural secara keseluruhan dilakukan terlebih dahulu uji unidimensionalitas pada masing-masing konstruk dengan analisis faktor konfirmatori. Uji unidimensionalitas ini dilakukan untuk mengetahui apakah indikator-indikator pengukur konstruk sudah memberikan hasil yang reliabel.

Analisis konfirmatori dilakukan antar variabel eksogen dan antar variabel indogen. Pada model ini ada variabel eksogen yaitu kepercayaan epistemologis sedangkan untuk variabel endogen yaitu konsepsi tentang belajar dan mengajar. Berdasarkan hasil analisis konfirmatori antar variabel eksogen dan antar variabel indogen menunjukkan bahwa nilai kriteria fit telah tercapai dengan baik. 
Begitu pula nilai signifikansi dari estimasi parameter standarized loading semuanya di atas 0,05, sehingga dapat dikatakan fit.

Setelah beberapa syarat yang diajukan terpenuhi, maka langkah berikutnya adalah menguji hipotesis berupa menguji data model teoritis dengan data empiris secara keseluruhan, yang hasilnya sebagaimana pada gambar 1 .

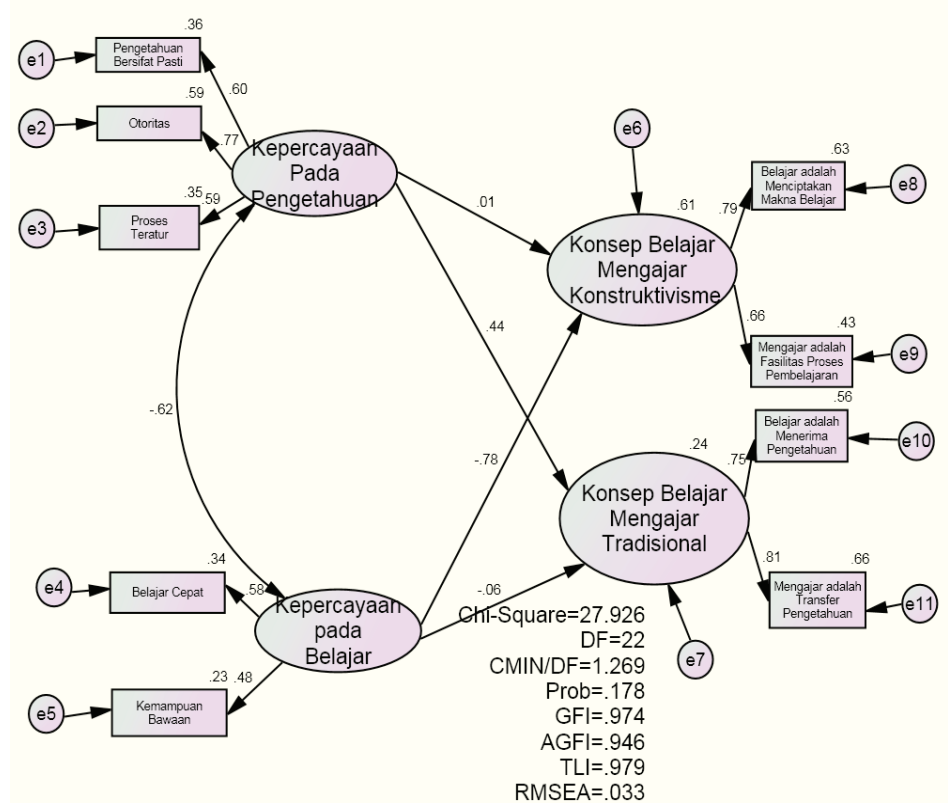

Gambar 1: Hasil Analisis Hubungan Kepercayaan Epistemologis dengan Konsepsi tentang Belajar dan Mengajar Mahasiswa.

Berdasar pada gambar 1 menunjukkan bahwa chi-square 27 , $926(\mathrm{DF}=22, \mathrm{p}=0,178), \mathrm{CMIN} / \mathrm{DF}=1,269, \mathrm{GFI}=0,974, \mathrm{AGFI}=0,946$, TLI $=0,979$ dan RMSEA $=0,033$. Dengan demikian kriteria syarat penerimaan model dapat terpenuhi, dikarenakan skor probabilitas masih di atas 0,05.

Berdasarkan pada hasil tersebut maka model yang digunakan ini dapat digunakan dalam penelitian ini. Hal ini berarti, bahwa model yang dirancang dalam penelitian ini (model teoretis) sesuai 
atau layak, dengan perolehan data yang dikumpulkan (model empiris) dapat diterima.

Melalui program statistik AMOS dapat dianalisis dan dihitung evaluasi hasil bobot regresi antar variabel laten yang sering disebut sebagai estimasi loading factors atau lambda value. Selain itu derajat bebas atau degree of freedom ( $d f$ ), nilai C.R atau t-hitung juga dapat diketahui. Berdasarkan signifikansi t-hitung dengan nilai probabilitas $(p)=0.05$. Hasil bobot regresi uji kausalitas disajikan pada tabel 3 .

Tabel 3

Hasil Bobot Regresi Uji Kausalitas

\begin{tabular}{|c|c|c|c|c|}
\hline Hubungan antar Variabel & Estimate & S.E. & C.R & $p$ \\
\hline $\begin{array}{l}\text { Kepercayaan pada Pengetahuan } \\
\text { terhadap konsepsi tentang } \\
\text { Belajar dan Mengajar } \\
\text { Konstruktivisme }\end{array}$ & 0,015 & 0,280 & 0,055 & 0,956 \\
\hline $\begin{array}{l}\text { Kepercayaan pada Belajar } \\
\text { terhadap Konsepsi tentang } \\
\text { Belajar dan Mengajar } \\
\text { Konstruktivisme }\end{array}$ & $-0,935$ & 0,329 & $-2,844$ & 0,004 \\
\hline $\begin{array}{l}\text { Kepercayaan pada Pengetahuan } \\
\text { terhadap Konsepsi tentang } \\
\text { Belajar dan Mengajar Tradisional }\end{array}$ & 1,285 & 0,400 & 3,210 & 0,001 \\
\hline $\begin{array}{l}\text { Kepercayaan pada Belajar } \\
\text { terhadap Konsepsi tentang } \\
\text { Belajar dan Mengajar Tradisional }\end{array}$ & $-0,156$ & 0,338 & $-0,462$ & 0,644 \\
\hline $\begin{array}{l}\text { Penjelasan lebih lanjut an } \\
\text { adalah bahwa variabel keper } \\
\text { memengaruhi terhadap konsep } \\
\text { konstruktivisme juga pada varia } \\
\text { memengaruhi terhadap konsep } \\
\text { tradisional karena signifikansi } \\
\text { Sementara pada variabel keperc } \\
\text { terhadap konsepsi tentang bel } \\
\text { juga pada variabel kepercayaan } \\
\text { terhadap konsepsi tentang bela } \\
\text { signifikansi t-hitung lebih kecil }\end{array}$ & $\begin{array}{l}\text { lisis evalua } \\
\text { cayaan pa } \\
\text { si tentang } \\
\text { bel keperca } \\
\text { i tentan } \\
\text { t-hitung } 1 \\
\text { ayaan pada } \\
\text { ajar dan me } \\
\text { pada pen } \\
\text { ar dan men } \\
\text { ari } 0,05 \text {. }\end{array}$ & $\begin{array}{l}\text { i bobo } \\
\text { la pen } \\
\text { belaja } \\
\text { yaan p } \\
\text { belaj. } \\
\text { ebih be } \\
\text { belaja } \\
\text { ngajar } \\
\text { getahua } \\
\text { gajar tr }\end{array}$ & $\begin{array}{l}\text { regresi } \\
\text { getahua } \\
\mathrm{r} \text { dan } n \\
\text { ada bela } \\
\text { ir dan } n \\
\text { sar dar } \\
\text { meme } \\
\text { konstru } \\
\text { n meme }\end{array}$ & $\begin{array}{l}\text { tersebut } \\
\text { an tidak } \\
\text { mengajar } \\
\text { ajar tidak } \\
\text { mengajar } \\
\text { ri } 0,05 . \\
\text { engaruhi } \\
\text { lktivisme } \\
\text { engaruhi } \\
\text { al karena }\end{array}$ \\
\hline
\end{tabular}


Adapun koefesien determinasi (R2) konsepsi tentang belajar dan mengajar konstruktivisme sebesar 0,61, yang bermakna bahwa 61 persen dapat dijelaskan atau diprediksi melalui variabel kepercayaan pada pengetahuan dan kepercayaan pada belajar. Koefesien determinasi (R2) konsepsi tentang belajar dan mengajar sebesar 0,24, yang bermakna bahwa 24 persen dapat dijelaskan atau diprediksi melalui variabel kepercayaan pada pengetahuan dan kepercayaan pada belajar.

\section{Pembahasan}

Tujuan penelitian ini secara umum adalah untuk membuktikan apakah kepercayaan pada pengetahuan dan kepercayaan pada belajar berpengaruh terhadap konsepsi tentang belajar dan mengajar konstruktivisme dan konsepsi tentang belajar dan mengajar tradisional.

Berdasar hasil analisis menunjukkan bahwa variabel kepercayaan pada pengetahuan tidak berpengaruh terhadap konsepsi tentang belajar dan mengajar konstruktivisme karena signifikansi t-hitung lebih besar dari 0,05. Sedangkan pada variabel kepercayaan pada belajar berpengaruh (negatif) terhadap konsepsi tentang belajar dan mengajar konstruktivisme sebesar -0,776 dengan signifikansi t-hitung lebih kecil dari 0,05.

Sementara pada variabel kepercayaan pada pengetahuan berpengaruh (positif) terhadap konsepsi tentang belajar dan mengajar tradisional sebesar 0,443 dengan signifikansi t-hitung lebih kecil dari 0,05 . Sedangkan pada variabel kepercayaan pada belajar tidak berpengaruh terhadap konsepsi tentang belajar dan mengajar tradisional karena signifikansi t-hitung lebih besar dari 0,05 .

Berdasarkan hasil penelitian ini dapat diketahui bahwa konsepsi tentang belajar dan mengajar konstruktivisme mahasiswa lebih dipengaruhi oleh kepercayaan pada belajar sedangkan pada konsepsi tentang belajar dan mengajar tradisional lebih dipengaruhi oleh kepercayaan mahasiswa pada pengetahuan.

Adanya pengaruh kepercayaan pada belajar secara negatif 
terhadap konsepsi tentang belajar dan mengajar konstruktvisme dikarenakan kepercayaan tentang bagaimana mendapatkan pengetahuan atau kepercayaan belajar, akan berpengaruh pula terhadap perilaku belajar mahasiswa, seperti kepercayaan mahasiswa sekitar berapa banyak waktu yang dibutuhkan untuk belajar mata kuliah tertentu. Apakah mata kuliah tersebut bisa dipelajari dengan cepat (quick learning) atau merupakan proses berangsur-angsur bisa dengan mudah atau perlu kerja keras, dan juga kepercayaan terhadap kemampuan atau kecerdasan dalam memperoleh pengetahuan (innate ability) yang bersifat bawaan yang menetap ataukah dapat berkembang setiap saat.

Berdasarkan penemuan dari studi-studi empiris sebelumnya pada belajar dan kecerdasan Dwick dan Leggett (dalam Tasaki, 2001: 13) berpendapat bahwa ada dua teori yang terkandung dari kecerdasan: (a) teori kecerdasan incremental dan (b) teori kecerdasan kesatuan (entity). Individu yang percaya teori incremental cenderung memandang kecerdasan dapat dirubah, dan dapat diperbaiki. Berbeda, individu yang memufakati teori kecerdasan kesatuan percaya bahwa kecerdasan tidak dapat berubah dan menetap. Dua kepercayaan tentang kecerdasan mengarahkan individu yang satu dengan yang lainnya untuk bereaksi dengan cara yang berbeda-beda ketika menjalankan aktivitas belajar termasuk pendekatan belajarnya. Individu yang memegang kepercayaan incremental cenderung untuk melihat aktivitas belajar sebagai suatu kesempatan untuk meningkatkan kecerdasan. Pada sisi lain, individu dengan kepercayaan kesatuan merasa aktivitas belajar tidak banyak berpengaruh terhadap aktivitas belajarnya dan hanya sebagai suatu kesempatan untuk menguji kecerdasannya saja.

Hasil penelitian ini juga membuktikan bahwa ada pengaruh kepercayaan pada pengetahuan terhadap konsepsi tentang belajar dan mengajar tradisional. Hasil penelitian ini menegaskan kembali pendapat Dweck dan Leggett (dalam Tasaki, 2001: 13) bahwa prilaku belajar individu sangat dipengaruhi oleh kepercayaan-kepercayaan mahasiswa sekitar sifat pengetahuan dan kemampuan mahasiswa.

Paulsen dan Feldman (dalam Chan, 2003: 36-50) berpendapat bahwa mahasiswa yang mempunyai kepercayaan rendah atau 
bahkan tidak mempercayai pada struktur pengetahuan seperti pengetahuan berstruktur sederhana akan mempunyai sedikit orientasi tujuan belajar yang intrinsik, dalam menghargai aktivitas belajar, dalam mengontrol belajar dan untuk merasakan bahwa individu tersebut dapat menjalankan sebuah tugas pada sebuah tingkat tertentu dalam belajar. Demikian pula kepercayaan mahasiswa tentang stabilitas pengetahuan seperti pengetahuan yang absolut, tentatif atau bersifat sementara dan kepercayaan mahasiswa tentang sumber pengetahuan bahwa pengetahuan berasal dari orang yang lebih tahu (omniscient), dari pengalaman orang yang mempunyai authoritas dalam menyampaikan pengetahuan atau berasal dari pemikiran sendiri diikuti dengan berbagai bukti.

Hofer \& Pintrich (1997: 88-140), mengklaim bahwa kepercayaan epistemologis secara umum memainkan peran penting di dalam perilaku-perilaku akademis, seperti mempengaruhi penggunaan teknik-teknik dalam belajar. Sebagai contoh, mahasiswa yang percaya bahwa struktur pengetahuan terdiri dari potonganpotongan yang tidak bertalian dengan informasi yang lainnya, kemungkinan akan menggunakan teknik menghafal sebagai teknik belajar (strategi permukaan) dan bukan tehnik pemahaman (strategi pendalaman). Penelitian ini juga menyimpulkan bahwa mahasiswa yang memandang bahwa pengetahuan sama yang tak berubah dan stabil cenderung menggunakan tehnik menghafal fakta-fakta ilmiah (strategi permukaan). Berbeda dengan mahasiswa yang memandang pengetahuan dinamis, yang akan lebih mengutamakan aspek pemahaman informasi atau strategi pendalaman. Lebih dari itu, mahasiswa yang percaya bahwa tehnik memahami (strategi pendalaman) adalah strategi terbaik dalam belajar, akan mempunyai hasil yang lebih baik pada saat ujian akhir dibandingkan dengan mahasiswa yang percaya bahwa tehnik menghafal adalah tehnik yang terbaik.

Bra ten dan Strømsø (2005: 539-565) menemukan pada mahasiswa yang percaya bahwa pengetahuan bersifat stabil dan hanya bisa diperoleh melalui otoritas pengajar, akan lebih sedikit mempunyai tujuan berorientasi pemahaman (strategi pendalaman) dan lebih banyak berorientasi penghafalan (strategi permukaan). Hasil penelitian (misalnya Chan, 2003: 36-50) juga menunjukkan 
bahwa kepercayaan epistemologis yang dimiliki oleh mahasiswa berhubungan secara signifikan dengan pendekatan belajar baik secara mendalam dan permukaan.

Berdasarkan hasil penelitian ini membuktikan pula bahwa kepercayaan pada belajar tidak berpengaruh terhadap konsepsi tentang belajar dan mengajar tradisional serta kepercayaan pada pengetahuan seperti kepercayaan mahasiswa pada pengetahuan yang sifatnya pasti (certain knowledge), pengetahuan berasal dari orang yang lebih tahu/seorang yang ahli (authority/ expert knowledge), dan didapatkan melalui proses yang teratur (orderly process) tidak berpengaruh terhadap konsepsi tentang belajar dan mengajar konstruktivisme karena dimungkinkan sampel berasal dari mahasiswa STAIN Kudus adalah lulusan dari madrasah dan pondok pesantren yang notabene sangat hormat dengan kyai, guru atau dosen. Selain itu, penekanan bahwa pengetahuan diwariskan oleh otoritas dan sangat menghormati posisi seorang pengajar. Pertimbangannya adalah bahwa pengajar dianggap sebagai profesi yang paling dihormati sehingga mempunyai perbedaan status dalam hubungan Dosen-mahasiswa. Bahkan dalam hubungan komplementer antara pengajar dan mahasiswa, pengajar diharapkan berperan seperti menjadi "mentor" yang kadang tidak hanya bertanggung jawab bagi mahasiswa belajar tetapi juga untuk masalah-masalah pribadi mereka.

Salah satu hal yang menarik pada ajaran Islam ialah penghargaan Islam yang sangat tinggi terhadap pengajar atau guru. Begitu tingginya penghargaan itu sehingga menempatkan kedudukan guru setingkat di bawah kedudukan nabi dan rasul, karena pengajar atau guru selalu terkait dengan ilmu (pengetahuan), sedangkan Islam sangat menghargai pengetahuan. Sebenarnya tingginya kedudukan seorang pengajar atau guru dalam Islam merupakan realisasi ajaran Islam itu sendiri. Islam memuliakan pengetahuan, Karena Islam adalah agama, maka pandangan dan kedudukan tentang seorang pengajar atau guru, tidak terlepas dari nilai-nilai keagamaan. Ada penyebab khas mengapa orang Islam amat menghargai guru, yaitu pandangan bahwa ilmu (pengetahuan) itu semuanya bersumber pada Tuhan. 
Penelitian kepercayaan mahasiswa tentang sifat pengetahuan dan bagaimana mengetahui, serta bagaimana kepercayaan epistemologis berhubungan dengan ide-ide mahasiswa tentang pengajaran dan belajar, dapat menyebabkan pemahaman yang lebih baik tentang bagaimana pengembangan intelektual dan pembelajaran yang dilakukan mahasiswa (Hofer 2001).

Beberapa hasil penelitian (seperti Chan, 2004; 2007; Chai, Teo dan Lee, 2010; Otting, Zwaal, Tempelaar dan Gijselaers, 2010 dan Lee, 2011) menunjukkan bahwa kepercayaan epistemologis berpengaruh signifikan terhadap konsepsi tentang belajar dan mengajar mahasiswa. Posisi kepercayaan epistemologis juga dapat menentukan posisi konsepsi tentang belajar dan mengajar yang dimiliki mahasiswa bahkan dapat mengembangkan konsepsi tentang belajar dan mengajarnya.

\section{Kesimpulan}

Berdasarkan hasil penelitian ini dapat disimpulkan bahwa kepercayaan pada belajar berpengaruh (negatif) terhadap konsepsi tentang belajar dan mengajar konstruktivisme. Semakin tinggi mahasiswa yang percaya bahwa belajar dapat dilakukan dengan cepat dan percaya bahwa belajar bersifat bawaan semakin rendah mahasiswa mempunyai konsepsi tentang belajar dan mengajar secara konstruktivisme.

Berdasarkan hasil penelitian ini juga temukan bahwa kepercayaan pada pengetahuan berpengaruh (positif) terhadap konsepsi tentang belajar dan mengajar tradisional. Artinya semakin tinggi mahasiswa yang percaya bahwa pengetahuan bersifat pasti tidak berubah dan tidak berkembang, pengetahuan berasal dari orang yang lebih tahu tidak berasal dari eksplorasi diri dan menunjukkan bukti-bukti ilmiah serta pengetahuan bersifat sederhana tidak mempunyai keterkaitan antara konsep yang satu dengan yang lainnya maka semakin tinggi pula mahasiswa mempunyai konsepsi tentang belajar dan mengajar secara tradisional dimana mengajar dipandang sebagai transfer pengetahuan dan belajar adalah hanya untuk menerima pengetahuan. 


\section{Daftar Pustaka}

Barnard, L., Lan, Y.L., Crooks, M.S.dan Paton, V.O. 2008. The Relationship Between Epistemological Beliefs and Self-regulated Learning Skills in the Online Course Environment. MERLOT Journal of Online Learning and Teaching. 4, 261-266

Boffeli, T.J. 2007. College Students' Personal Epistemological Belief as Factors in Academic Procrastination. Unpublished doctoral dissertation. Capella University.

Bra॰ten, I. \& Strømsø, H.I. 2005. The relationship between epistemological beliefs, implicit theories of intelligence, and self-regulated learning among Norwegian postsecondary students. British Journal of Educational Psychology, 75, 539-565

Bra॰ten, I. \& Strømsø, H.I. 2006. Epistemological beliefs, interest, and gender as predictors of Internet-based learning activities. Computers in Human Behavior, 22,1027-1042.

Brownlee, Joanne M. and Thorpe, Karen J. and Stacey, Phillip S. 2005. Improving learning and teaching in early childhood teacher education: A focus on personal epistemology. In Proceedings Higher Education Research and Development Society of Australasia, Sydney, NSW

Cano, F. 2005. Epistemological beliefs and approaches to learning: Their change through secondary school and their influence on academic performance. British Journal of Educational Psychology, 75, 203-221.

Chai, S. C, Teo, T. \& Lee, C. B. 2010. Modelling the Relationships among Beliefs about Learning, Knowledge, and Teaching of Pre-Service Teachers in Singapore. The Asia-Pacific Education Researcher, 19, 25-42

Chan, K. 2003. Hong Kong teacher education students' epistemological beliefs and approaches to learning. Journal Research in Education, 
69, 36-50

Chan, K. 2004. Preservice Teachers' Epistemological Beliefs And Conceptions About Teaching And Learning : Cultural Implications For Research In Teacher Education. Australian Journal of Teacher Education, 1, 1-13

Chan, K. 2007. Hong Kong Teacher Education student's Epistemological Beliefs and their Relations with Conceptions of Learning and Learning Strategies. The Asia Pacific-Education Researcher, 16, 199-214.

Chan, K. W. \& Elliott, R. G. 2004. Relational analysis of personal epistemology and conceptions about teaching and learning. Teaching and Teacher Education, 20, 817-831.

Chan, K., dan Elliott, R.G. 2004. Epistemological Belief Across Cultures; Critique and Analysis of beliefs Structure Studies. Educational Psychology, 24, 123-142

Chan, K., Tan, J., \& Khoo, A. 2007. Pre-service teachers' conceptions about teaching and learning: A closer look at Singapore cultural context. Asia-Pacific Journal of Teacher Education, 35(2), 181-195.

Davis, E.A. 1997. Students. Epistemological Beliefs about Science and Learning. Paper presented at the Annual Meeting of the American Educational Research Association, Chicago, IL.

Ghufron, M. Nur. 2009. Hubungan antara Kepercayaan Epistemologi dan Pendekatan Belajar: Studi Metaanalisis. Jurnal Psikologi. 36, 130-143

Hofer, B.K. 2001. Personal epistemology research: Implications for learning and teaching. Educational Psychology Review, 133, 353-382.

Hofer, B.K. dan Pintrich, P.R. 1997. The Development of Epistemological Theories: Beliefs About Knowledge and Knowing and Their Relation to Learning. Review of Educational Research, 67, 88-140 
Horwitz, E.K. 1988. The beliefs about language learning of beginning university foreign language students. Modern Language Journal, 72(3), 283-294

Jehng, J.C., Johnson, S.D. \& Anderson, R.C. 1993. Schooling and students' epistemological beliefs about learning. Contemporary Educational Psychology, 18, 23-25.

Kember, D. 1997. A reconceptualisation of the research into university academics' conceptions of teaching. Learning and Instruction, 7(3), 255-275.

King, P. M., \& Magolda, M.B. 1996. A developmental perspective on learning. Journal of Collage Student Development, 37, 163-173.

Lee, S. 2011. Trajectories Toward Becoming A Teacher: Exploring The Developmental Processes Of Preservice Teachers' Conceptions Of Teaching And Their Teacher Identities. Unpublished doctoral Dissertation. The University of Texas at Austin

Liem, G. A. D., \& Bernardo, A. B. I. 2010. Epistemological beliefs and theory of planned behavior: Examing beliefs about knowledge and knowing as distal predictors of Indonesian tertiary students' intention to study. The AsiaPacific Education Researcher, 19, 127-142

Otting, H., Zwaal, W., Tempelaar, D. dan Gijselaers, W. 2010. The structural relationship between students' epistemological beliefs and conceptions of teaching and learning. Studies in Higher Education. Vol. 35, No. 7, November 2010, $741-760$

Phan, P. H. 2006. Examination of student learning approaches, reflective thinking and epistemological belief. Electronic Journal of Research in educational Psychology, 4, 577-610

Ryan, M. P. 1984. Monitoring text comprehension: Individual differences in epistemological standards. Journal of Educational Psychology, 76, 1226-1238. 
Schoenfeld, A.H. 1983. Beyond the purely cognitive: Belief systems, social cognitions, and metacognitions as driving forces in intellectual performance. Cognitive Science, 7, 329-363.

Schommer, M. 1990. Effects of beliefs about the nature of knowledge on comprehension. Journal of Educational Psychology, 82, 498-504.

Schommer, M. 1993a. Comparisons of beliefs about the nature of knowledge and learning among postsecondary students. Research in Higher Education, 34, 355-370.

Schommer, M. 1993b. Epistemological development and academic performance among secondary students. Journal of Educational Psychology, 85, 406-411.

Schommer, M. 1994. Synthesizing epistemological belief research: Tentative understandings and provocative confusions. Educational Psychology Review, 6, 293-319

Schommer, M. A. 2004. Explaining the Epistemological Belief System: Introducing the Embedded Systemic Model and Coordinated Research Approach. Educational Psychologist, 39, 19-29

Songer, N. B., \& Linn, M. C. 1991. How do students' views of science influence Knowledge integration? In M. C. Linn, N. B. Songer, \& E. L. Lewis (Eds.), Students' models and epistemologies of science (Vol. 28, pp. 761-784).

Stephen, I dan William, M. 1981. Handbook in Research and Evaluation. San Diego, California: EDITS Publishers.

Tasaki, K. 2001. Culture And Epistemology: An Investigation of Different Patterns in Epistemological Beliefs Across Culture. Unpublished doctoral dissertation. University of Hawaii.

Tsai, C. C. 2000. Relationships between student Scientific epistemological beliefs and perceptions of constructivist learning environments. Educational Research, 42, 193205 
Tsai, C.C. dan Chuang, S.C. 2005. The correlation between epistemological beliefs and preferences toward Internetbased learning environments. British Journal of Educational Technology, 36, 97-100.

Tynjälä, P. 1999. Towards expert knowledge? A comparison between a constructivist and a traditional learning environment in the university. International Journal of Educational Research, 31(5), 357-442

Weinstein, C.S. 1990. Prospective elementary teachers' beliefs about teaching: Implications for teacher education. Teaching and Teacher Education, 6(3), 279-290.

Zerin, E. 1995. Methods of Human Knowing. Transactional Analysis Journal, 25, 150-155) 